\title{
Proč se chci stát učitelkou v mateřské škole? Pohled kvalitativního výzkumu
}

\author{
Adriana Wiegerováa, Peter Gavora ${ }^{\mathrm{b}}$ \\ a Univerzita Tomáše Bati ve Zlíně, Fakulta humanitních studií, Ústav školní pedagogiky \\ b Univerzita Tomáše Bati ve Zlíně, Fakulta humanitních studií, Centrum výzkumu
}

Redakci zasláno 27. 4. 2014 / upravená verze obdržena 13. 7. 2014 /

k uveřejnění přijato 15. 7. 2014

\begin{abstract}
Abstrakt: Příspěvek referuje o výzkumu motivů volby profese učitelky mateřské školy. Vzorek se skládá z 29 studentek bakalářského studia učitelství v mateřské škole na jedné moravské univerzitě. Výzkumnou metodou bylo tematické psaní o motivech, proč se studentky chtějí stát učitelkami v mateřské škole, jaké byly okolnosti jejich rozhodnutí a též o tom, jaké je jejich pojetí dítěte a dětství a koncepce činnosti učitelky mateřské školy. Tematické psaní bylo zadáno dvakrát, v prvním a třetím semestru studia. Texty byly analyzovány s cílem hledat odpovědi na výzkumné otázky. Výsledky ukazují, že rozhodnutí stát se učitelkou v mateřské škole je výsledkem předcházejících složitých interakcí mezi osobnostními charakteristikami subjektu a externími faktory, jejichž vliv však subjekt nepřijímá pasivně, ale filtruje je přes své dosavadní postoje a přesvědčení. U participantek se ukázaly dva významné osobnostní faktory - feminita a emocionalita. Pokud jde o externí determinanty, silným faktorem bylo prostředí rodiny, která poskytla př́ležitosti pro herní činnosti, které participantky realizovaly s dětmi, a rolové modely. Předprofesionální zkušenosti vyústily do pojetí učitelství v mateřské škole jako prodlouženého dětství. Edukační filozofie participantek spočívá ve třech rolích učitelky: ochranářské, průvodce dítěte z dětství do života a průvodce při vstupu do školního života.
\end{abstract}

Klíčová slova: učitelka mateřské školy, rozhodnutí být učitelem, feminita, emocionalita, předprofesionální zkušenosti, koncept učitelství

Rozhodnutí začít studovat na fakultě, která nabízí učitelské směry, je předpokladem, že se mladý člověk stane učitelem. Předpoklad se v mnohých (tedy ne všech) případech stane skutečností. Poznání motivů studentů, které je vedly $\mathrm{k}$ volbě učitelského studia, je důležitou informací, jež vypovídá nejen o jejich kariérním rozhodnutí, ale také o situacích, událostech a osobách, které k tomuto rozhodnutí přispěly. Přímo či nepřímo také vyjadřují vztah mladých lidí k učitelství jako povolání a vypovídají o tom, jak se tento vztah vyvíjel a for- 
moval. Vzhledem k tomu, že tato rozhodnutí, postoje, hodnoty a přesvědčení nevznikají ve vzduchoprázdnu, ale na základě prožitých zkušeností, doplňují a prohlubují náš obraz o studentech učitelství o méně poznanou a uvědomovanou a rovněž méně analyzovanou složku. Nejde tedy jen o rozhodnutí stát se učitelem. Toto je první fází vývoje mladého člověka od ne-učitelství k učitelství. Výzkum ukazuje, že začátky této cesty jsou nejvýznamnějším obdobím na cestě k profesionalitě. Proces přerodu je však dlouhý, kontinuální a spolupůsobí v něm rodinné, sociální i akademické vlivy stejně jako specifika osobnosti jednotlivých aktérů.

Ve studii odhalujeme kontext, v němž se rodilo rozhodnutí participantek stát se učitelkou mateřské školy. Tento kontext bude naplněn percepcí dětství a dítěte participantkami výzkumu a jejich představami o fungování učitelky mateřské školy. Ukážeme též zdroje inspirace, které spolupůsobily při rozhodnutí stát se učitelkou mateřské školy, jakými byly praktické aktivity participantek s dětmi a rodinné prostředí včetně rolových vzorů. Nakonec popíšeme příběh rozhodování vydat se na dráhu učitelky mateřské školy od předběžné idey k rozhodnutí definitivnímu.

\section{Teoretický rámec}

V této studii vycházíme z toho, že stát se učitelem je personální a sociální proces. Volba studia učitelství je produktem minulých individuálních zkušeností osoby, jejích mezilidských interakcí a jednání v konkrétním sociálním a kulturním prostředí a opírá se o individuálně konstruovaný koncept učitelství. Neexistuje předem daný vrozený koncept učitelství. Tento koncept si lidé postupně vytvářejí. Konstruování je na jedné straně sociálním procesem (probíhá v rámci mezilidských interakcí a pozorování sociálních modelů a rolí), na druhé straně je to proces osobní (vnitřní interpretace prožitých zkušeností a významů). Při teoretické koncepci této studie jsme se inspirovali vícero teoretickými proudy, především symbolickým interakcionismem a sociálním konstruktivismem (Blumer, 1969; Buckenham, 1998; Epting \& Paris, 2006; Gergen, 1985; Kelly, 1995; Mallon, 2007). Podnětné pro nás byly taktéž domácí práce zaměřené na zkoumání identity učitele (Juklová, 2013; Lukas \& Švaříček, 2007; Švaříček, 2009).

Učitelství je sociální kategorie. Neexistuje a priori, ani mimo člověka. Je vytvářená a fixovaná v sociálních aktech, tj. činnostech, v nichž lidé vstupují do vzájemných interakcí a vyměňují si významy. Sociální akt je ve společnosti 
uznávané cílevědomé chování, a to verbální i neverbální, přímé a zprostředkované (tištěné slovo, mobil, TV), jehož prostřednictvím a $v$ jehož rámci si člověk vytvář́ nové významy a zjemňuje, zpřesňuje a fixuje už existující významy. V sociálních aktech však nejde jen o vytváření a zpřesňování významů. Sociální kategorie se na jedné straně konstruuje, na druhé straně slouží jako interpretační rámec, pomocí něhož člověk chápe věci a jevy okolo sebe a v souladu s nímž pak jedná.

Vytváření sociální kategorie učitel začíná v dětství - na základní škole, resp. podle situace už v mateřské škole. Dítě je účastníkem sociálních aktů v prostředí školního zařízení, interaguje s učiteli a spolužáky, vnímá a interpretuje komunikované edukační obsahy. $V$ průběhu vzdělávací cesty si neustále zpřesňuje a prohlubuje sociální kategorii učitel.

Koncept učitelství si konstruují všichni lidé, kteří mají životní zkušenosti se školním vzděláváním. Avšak u těch, kdo jsou učiteli, nebo jsou na cestě k této profesi, dochází ke zdvojené konstrukci. Tou druhou je budování identity učitele. Sociální konstrukt učitel se individualizuje, stává se součástí Já. Přitom se tito lidé konformují, přizpůsobují se vžitému konceptu učitele ve společnosti, tj. jeho hodnotám, očekáváním, chování, protože s ním nemohou být $\mathrm{v}$ rozporu - vystoupili by z role učitele, případně by se dostali do konfliktu a čelili by možným sociálním sankcím (např. ignoraci, sankcím apod.). Osobní (individuální) identita učitele vzniká ve svébytném procese, jehož produktem je unikátní učitel. Důkazem toho je, že co se týká jeho charakteristiky jako preference, hodnoty, postoje, zkušenosti a jednání, neexistují identičtí učitelé. Každý učitel je originální osobností, má vlastní identitu.

Konstrukce profesní identity učitele je kontinuální, trvalý a nepřestávající proces, přičemž nejtvárnějším obdobím je začátek profesní kariéry učitele. V první fázi se vytváří jistý prekoncept učitele, $v$ dětství často herně realizovaný ve formě učitelské sebeprezentace (Gavora, 2002). Vlivem dalších situací (životních, akademických, profesních) se tento prekoncept prohlubuje. Mladý člověk získává postoje, přesvědčení, vědomosti a názory typické pro profesi učitele, akceptuje normy a pravidla učitelství. Tyto normy a pravidla mladý člověk nezískává jen pozorováním situací, ale aktivní interakcí, v níž se jednotlivé významy vyměňují, vysvětlují a precizují. Mladý člověk dospívá ke stále hlubšímu pochopení své role, což probíhá nejen v procesu konstrukce, ale i rekonstrukce identit (Spilková et al., 2004). Uvedené procesy probíhají nejen vědomě, ale často implicitně, nevědomky (Stuchlíková, 2006). 
K tomu, aby se určitá identita konstruovala, nestačí jen sociální a kognitivní procesy. Člověk potřebuje určitý emocionální podklad, aby byl vnímavý k sociálním kategoriím a aby se angažoval v konstrukčním procese. Proto je při vytváření sociální kategorie vždy důležitá afektivní stránka procesu konstrukce. Nefunguje jako jeho doplněk, ale jako významná součást. Hodnoty, postoje a emoce aktérů jsou důležitým základem tohoto konstruování. V př́ipadě učitele je afektivní stránka konstrukčního procesu velmi silná i proto, že o povolání učitele se ucházejí (či měli by se ucházet) lidé s hodnotami, jako je altruismus a pozitivní vztah $\mathrm{k}$ dětem.

\section{Dosavadní výzkum}

Pro potřeby analýzy domácí a zahraniční literatury popisující motivy ucházení se o studium učitelství v mateřské škole jsme uskutečnili vyhledávání časopiseckých studií v katalozích Národní knihovny ČR a Slovenskej národnej knižnice. Rozpětí ročníků bylo nastavené na 1996-2014.

Základní poznatek z vyhledávání je ten, že produkce studií k této problematice je neobyčejně chudá. $V$ České republice se výzkumem motivace stát se učitelem mateřské školy zabývaly Burkovičová et al. (2011) a Šmelová a Nelešovská (2009). Jejich výzkumy, realizované na vzorcích studentů vlastní univerzity, přinesly zjištění, že k hlavním motivům stát se učitelem mateřské školy patři láska k dětem a vliv učitele střední školy. Častá byla také volba studia učitelství jako náhradní (Nic jiného mi nezbylo.).

Na rozdíl od malého počtu literárních zdrojů zabývajících se motivem ucházení se o studium učitelství v mateřské škole existují početnější výzkumy se širší koncepcí - mapují proces rozhodování se žáků základních a středních škol k dalšímu studiu širokopásmově. Takový je například výzkum Hlad’a a Drahoňovské (2012), který sledoval, jaké mají absolventi základních a středních škol preference při volbě další vzdělávací cesty, která predikuje možnou profesní dráhu. Výzkum potvrdil, že při rozhodování se žákủ a studentů hrají nejdůležitější roli jejich rodiče, př́buzní a kamarádi. Důležitým zjištěním bylo také, že při rozhodování mají žáci základních a středních škol vlastní preference, za kterými si stojí.

V roce 2002 byl na Slovensku realizován výzkum se vzorkem 11 učitelů, kteří vyprávěli svůj životní příběh (Gavora, 2002). Výzkum se zaměřil na rozhodování stát se učitelem mateřské a základní školy. K významným zjištěním 
i zde patřilo, že na rozhodnutí mělo důležitý vliv rodinné prostředí v dětství, osobnostní vlastnosti mladého člověka, zkušenosti ze školy jako instituce, rolové vzory, klíčové osoby (v pozitivním smyslu charismatičtí lidé a v negativním antivzory) a zlomové životní události. Výzkum odhalil také etapy, během nichž vzniká rozhodnutí stát se učitelem - inspirace, prekoncept role učitele, identifikace s rolí učitele, prvotní vize profese, zpřesňování vlivem dalších zkušeností a rozhodnutí stát se učitelem. Ve výzkumu Karikové (2004) rekonstruovali učitelé prvního stupně ZŠ zpětně své motivy stát se učitelem. Tím rozhodujícím byla smysluplná práce $\mathrm{v}$ této profesi a možnost seberozvoje a odborného růstu.

V př́padě zahraniční literatury jsme prohledali databáze EBSCO a Proquest Central. Pro vyhledávání v abstraktech dokumentů byly zadány ty to výrazy:

První okénko:

- reasons to become a teacher,

- motives to become a teacher,

- reasons for becoming a teacher,

- motives for becoming a teacher,

- reasons for wanting to teach,

- motives for wanting to teach,

- interest in teaching.

Druhé okénko:

- preschool. $^{1}$

V cizojazyčné literatuře - podobně jako v české a slovenské - jsme taktéž nenašli velké množství studií, které by se př́mo vztahovaly ke sledování motivace stát se učitelem mateřské školy. Ačkoliv obě prohledané databáze obsahují desetitisíce fulltextových dokumentů, našli jsme jen dva texty, které odpovídaly vyhledávacím kritériím.

Prvním textem byla studie Erena (2012) z Turecka. Autor zjištoval pomocí dotazníků, (1) jaký je profil motivace studentů učitelství stát se učitelem

1 Vyhledávání za pomoci klíčového slova kindergarten přineslo množství studií ze Severní Ameriky, ve kterých se však tímto výrazem označuje nultý stupeň základní školy. Nejde tedy o preprimární vzdělávání. 
po ukončení vysoké školy a (2) zda tento profil má významný vztah ke spokojenosti s výběrem profese učitele a s profesními plány. Část vzorku, který pocházel z jedné vysoké školy, tvořili i studenti učitelství v mateřské škole. Další studenti studovali učitelství pro primární a sekundární stupeň. Výsledky o studentech učitelství pro mateřské školy nejsou prezentovány samostatně, ale jen společně s ostatními studenty. $V$ dotazníku autor zjistil významné motivy jako (a) zájem studentů o konkrétní vyučovaný předmět, (b) zájem o didaktickou stránku profese, (c) zájem o výchovnou stránku profese.

Druhá studie byla založená na kvalitativním výzkumu. Courtová, Meravová a Ornanová (2009) zkoumaly 10 učitelů mateřské školy z Izraele. Učitelé tvořili elitní vzorek - měli výbornou reputaci u kolegů a rodičů. Autorky zkoumaly důvody, proč se tyto osoby staly učitelkami a jak chápaly svou roli. Výzkumnou metodou bylo hloubkové polostrukturované interview a pozorování vyučovací činnosti učitelek, které bylo zdrojem otázek pro druhé interview. Důvodem volby učitelské profese byla osobní historie participantek, motivace $\mathrm{z}$ rodinného prostředí a vnímání potřeb a ambicí těchto participantek. U vícerých se rozhodnutí stát se učitelkou zrodilo už v dětském věku a největší vliv mělo rodinné prostředí. Participantky většinou vyrůstaly $\mathrm{v}$ rodině, kde matka, a př́ípadně i babička, byly učitelkami, takže budovaly generační profesní kontinuitu.

Získání jen dvou studií z vyhledávání v databázích neznamená, že se problematika motivů stát se učitelkou mateřské školy nezkoumá. Databáze EBSCO a Proquest Central se zaměřují na určité skupiny světových časopisů a jiné zanedbávají. Například studie Courtové et al. (2009) uvádí v literatuře další práce zabývající se touto problematikou, které vyšly v Izraeli a nejsou v použitých databázích dostupné. Na druhé straně to však ještě neznamená, že tato literatura je robustní - rozhodně je méně početná než v případě zkoumání motivů stát se učitelem na základní a střední škole.

Zmíněné motivy stát se učitelem na základní a střední škole mohou mít některé společné prvky s těmi pro učitelky mateřské školy. Častá je např́íklad inspirace učitelem ze základní a střední školy. Zásadním rysem u adeptek učitelství v mateřské škole je však vztah k dětem, který, jak uvidíme v našem výstupu, je velmi emocionální a sehrál rozhodující úlohu při volbě studia. Adeptky učitelství se cítí být povolány (calling) pro tuto profesi (Whitbeck, 2000). Pocit'ují výhodu učitelství v období, kdy mají malé děti, i když nízký společenský status učitele, špatné platové podmínky a přetíženost úkoly jsou 
faktory, které mohou učitele podnítit k odchodu z profese. (Thornton, Bricheno, \& Reid, 2002). Další autoři zdůraznili nejen vztah studentů učitelství k jiným učitelům, kteři sloužili jako vzory, ale také svoje osobnostní předpoklady pro tuto profesi. Profesní prekoncepce učitelů vznikaly postupně, a to během jejich žákovských let, přičemž se aktualizoval jejich dřivější identifikovaný potenciál (Malderez et al., 2007).

Malý počet výzkumů motivace ucházení se o studium učitelství pro mateřské školy pravděpodobně také odráží skutečnost, že předškolní pedagogika je poměrně mladou vědní disciplínou a není ještě pevně etablovaná. Do jisté míry svou negativní roli sehrává i to, že se postavení učitelky mateřské školy připisuje nižší status než jiným učitelům, a proto si údajně nezaslouží hlubší vědecké zkoumání. My se však domníváme, že jde o mylný postoj. Dále si myslíme, že malý počet literatury odpovídá pracovní pozici učitelky mateřské školy, která je koncipována odlišně od klasické pozice učitele. Učitelka mateřské školy působí v zařízení, které svou podstatou nepatří mezi instituce povinného charakteru. Mateřskou školu navštěvují děti takř́ikajíc dobrovolně, podle rozhodnutí rodičủ. Pokud by tam nechodili, rodiče nejsou nijak právně postihováni. Mateřská škola je tedy stále dobrovolnou institucí a pozice učitelky mateřské školy má jiný charakter než v př́ípadě nejčastěji porovnávaných učitelů prvního stupně.

\section{Výzkum}

Cílem našeho výzkumu bylo zjistit, jaké motivy vedly participantky výzkumu $\mathrm{k}$ rozhodnutí vydat se na dráhu učitelky $\mathrm{v}$ mateřské škole. Cílem bylo dále stanovit, ve kterém momentě života došlo $\mathrm{k}$ tomuto rozhodnutí a jak tento proces probíhal. Poněvadž všechna závažná osobní rozhodnutí se uskutečňují v konkrétním životním kontextu, zkoumali jsme zároveň, které faktory vedly participantky $\mathrm{k}$ tomuto rozhodnutí. $\mathrm{V}$ souladu se zásadami kvalitativního výzkumu nebyly tyto faktory stanoveny a priori, naopak byly ukryty $v$ datech, $\mathrm{z}$ nichž jsme je extrahovali.

\subsection{Výzkumná metoda}

Metodou sběru dat v tomto výzkumu bylo tematické psaní textu. Je to způsob volného autorského psaní, při němž participanti produkují text na zadané téma. Psaní je volné, tj. neřízené výzkumníkem - proud psaní jím není přerušovaný nebo jinak omezovaný. Tematické psaní je vlastně kvalitativním 
protikladem dotazníku, v němž respondenti odpovídají na řadu otázek stanovených výzkumníkem. Orientace tematického psaní je opačná. Výzkumník angažuje participanty do uvažování o sobě. Text, který produkují, je konstrukcí jejich vlastní subjektivity.

Volná písemná produkce je málo frekventovaným způsobem získávání dat v kvalitativním výzkumu, ačkoliv její výhody jsou zjevné (Elizabeth, 2007; Richardson, 1994)². V kvalitativním výzkumu spíše převládají orální metody sběru dat. Výhodou písemné metody je, že mediační efekt výzkumníka je menší v porovnání s interview, participant pracuje vlastním tempem a jeho postup není výzkumníkem přerušován.

Participantkám jsme vysvětlili záměr výzkumu a dali jim instrukce týkající se obsahu tematického psaní, jeho rozsahu a žánru. Obsah psaní byl daný těmito okruhy: důvody, proč se participantka chtěla stát učitelkou v mateřské škole, které okolnosti přispěly $\mathrm{k}$ jejímu rozhodnutí, jaké je její pojetí dětství a dítěte a představa o činnosti učitelky mateřské školy. Rozsah textu nebyl omezený a na jeho vypracování měly participantky čas 30 minut. Textový žánr byl definován jako písemná sebereflexe. Účast participantek ve výzkumu byla dobrovolná na základě získaného souhlasu.

Participantky psaly text $\mathrm{v}$ učebně při neformálním setkání s garantkou studijního oboru. Text odevzdaly anonymně. Psaní se uskutečnilo dvakrát, a to na konci prvního a na konci třetího semestru studia. Zatímco při prvním psaní dominovaly vzpomínky na rozhodování se při výběru studia a na reflexi prvotní identity učitelky, ve druhém případě byla tato identita vykreslena hlouběji společně se širším kontextem. První text byl kratší, nepřesáhl 400 slov, druhý text byl rozsáhlejší, pohyboval se od 333 do 823 slov (medián 614). Krátký rozsah zejména prvního psaní byl pro nás překvapením. Očekávali jsme širší a hlubší reflexi. Př́čina mohla spočívat ve slabé motivaci studentek podat o sobě písemnou zprávu anebo v nízké textové dovednosti uchopení tématu.

Participantky byly studentkami, které oba výzkumníci znali, protože je vyučovali, což pomáhalo při interpretaci některých údajů v textech.

Tematické psaní použili např. Spilková et al. (2004). Ve výzkumu učitele se používají i další kvalitativní metody získávání písemných dat: reflexivní deník a nedokončené věty (Kasáčová, 2005; Spilková et al., 2004; Wiegerová \& Lampertová, 2012). 
Základní metodu směřující ke zjištěním tvořila tematická analýza textu (Braun \& Clarke, 2006). Texty byly opakovaně čteny a potom podrobeny systematickému otevřenému kódování. Texty byly kódovány společně, přičemž cílem bylo harmonizovat postup a vytvořit společný úhel pohledu na kódované segmenty textu a na kódy. Výsledkem prvního stupně analýzy byly nakódované segmenty textů a seznam kódů. V druhém stupni analýzy byly kódy seskupeny do sémanticky sjednocených skupin, které dostaly název. Takto vznikla témata. $V$ průběhu analýzy byla tato témata porovnávána na úrovni participantek i na úrovni obou ročníků z hlediska kódů a témat $\mathrm{v}$ procesu zvaném konstantní komparace. Další etapou bylo prověřování relevance témat a jejich naplnění segmenty textu, přičemž se některá témata spojovala, aby vytvořila jiná témata, další se rozdělila. Paralelně s tím se rodila teoretická interpretace, která vyústila do modelu determinantů.

Snad není potřebné zdůraznit, že v souladu s principy kvalitativní metodologie data odrážejí subjektivní chápání rolí, vlastností a životních situací podaných participatkami, které se výzkumníci snažili interpretovat. Nejde tedy o neosobní výpověd' o sobě, místě a čase. Naopak, tato výpověd' je saturována osobními postoji, preferencemi a zkušenostmi. To nepovažujeme za nedostatek, ale za výhodu výzkumu tohoto typu.

\subsection{Participantky výzkumu}

Participantkami výzkumu byly studentky prezenčního bakalářského studia oboru Učitelství pro mateřské školy v jednom z moravských regionů. Sběr dat se uskutečnil ve dvou etapách. První etapa proběhla v akademickém roce 2012/2013, kdy studentky byly posluchačkami prvního ročníku, druhá etapa se uskutečnila o rok později, kdy studentky postoupily do druhého ročníku studia. Studentky byly ženy ve věku od 18 do 22 let. Polovina studentek skončila střední školu pedagogického zaměření a měla kvalifikaci učitele mateřské školy. Ostatní studentky přišly studovat učitelství na univerzitu z jiných odborných škol nebo gymnázia.

Některé studentky se pokoušely o studium na vysoké škole na druhý až třetí pokus. Mezidobí po ukončení střední školy a před studiem na univerzitě trávily praxí $\mathrm{v}$ mateřských školách anebo $\mathrm{v}$ organizacích, které se věnovaly edukačním aktivitám s dětmi předškolního věku. Povětšinou šlo o zájmové útvary typu taneční kroužek, kroužek lidového tance, keramický a pěvecký kroužek. Většina měla zkušenost s pobytovými aktivitami pro děti mladšího 
školního věku během letních prázdnin. Pracovaly bud' na pozici vedoucího v letním pobytovém táboře, nebo spolupracovaly při aktivitách, které byly organizované jako tzv. příměstský letní tábor. $\mathrm{Z}$ toho vyplývá, že všechny měly zkušenost $\mathrm{s}$ dětmi a více než polovina $\mathrm{z}$ nich kromě této zkušenosti absolvovala i během studia praxi na pedagogické akademii.

V prvním ročníku studovalo 30 studentek, z nichž se výzkumu zúčastnilo 29 (jedna studentka nebyla přítomná na vyučování v čase výzkumu), druhý ročník tvořilo 23 studentek, ze kterých se výzkumu zúčastnilo 22 (jedna studentka nebyla př́tomná ze stejného důvodu). Pro doplnění charakteristiky studentek dodáváme, že výběr do prvního ročníku studia byl poměrně přísný, bylo přijato jen $15 \%$ přihlášených uchazečů.

Pro lepší orientaci čtenáře připomínáme, že v ČR se učitelem mateřské školy může stát:

- absolvent střední odborné školy se zaměřením na přípravu učitelů MŠ;

- absolvent vyššího odborného vzdělávání zaměřeného na přípravu učitelů MŠ;

- absolvent programu celoživotního vzdělávání, organizovaného vysokou školou se zaměřením na přípravu učitelů MŠ;

- absolvent vysoké školy, která má akreditované studijní programy se zaměřením na přípravu učitelů pro mateřské školy. Jak již bylo uvedeno, participantky studovaly tento studijní program.

\subsection{Výzkumná zjištění}

Všechny participantky našeho výzkumu byly ženy. Tím byl dán silný determinační rámec volby studijní cesty, percepce role učitele a charakteru jeho činnosti. Genderová identita totiž vytváŕí určitou optiku, kterou participantky vnímaly svět, přičemž si zároveň budovaly genderové zařazení a jednaly podle něj. Gender přináší jistý filtr, který ovlivňuje vnímání a hodnocení situací, účast v nich, nebo vyhýbání se jim. Jak ukážeme, participantky konzistentně vyhledávaly genderově adekvátní situace, uplatňovaly adekvátní činnosti, vytvářely si odpovídající postoje a preference pro práci s dětmi. 


\section{Preference herních činností}

Pro většinu participantek byla inspirací pro volbu budoucí profese činnost $s$ dětmi, tedy vlastní zkušenosti, které $s$ dětmi předškolního věku participantky výzkumu měly. Tvořilo je zejména hlídání a péče o děti, hra s dětmi a vyprávění pohádek dětem.

Už od mala jsem se ráda starala o mladšího bratra a sestřenici. Vymýšlela jsem pro ně různé hry, stezky odvahy, vystoupení pro rodiče na různých rodinných oslavách. (...) Mám mladší sestry, dvě malé sestřenice a malinkého bratránka. ${ }^{3}$

Síla herních zážitků s dětmi byla někdy tak silná, že vedla k nárůstu kontaktů $s$ dětmi, přičemž to byla samotná participantka, kdo rozhodoval o tomto zintenzivnění, nešlo tedy o vynucenou situaci.

$\mathrm{V}$ průběhu studia jsem ve volném čase začala hlídat malé děti. Ze začátku to bylo jen po večerech maximálně 1 hodinu až 2 hodiny. Postupem času mě to ale s dětmi začalo bavit víc a víc. $Z$ jedné hodiny se stávaly tř̌i hodiny a postupně půl dne až celý den.

K inspiracím, jež potkaly participantky výzkumu s dětmi předškolního věku, patřily aktivity, které byly spontánní, volné a neformální. Nekladly velké organizační nároky na mladého člověka jako napřs sladění činnosti, jejich vhodná návaznost a gradace. Ve výpovědích nebylo možné najít vyjádření, jakou rozvíjející potencialitu jim participantky připisovaly. Šlo spíše o dozor, zábavu a trávení volného času. Proto tyto herní činnosti s dětmi interpretujeme jako prodloužení vlastního dětství, avšak o úroveň výše, prrípadně o vztah staršího prríbuzného k mladšímu, a to bud' metaforicky, anebo reálně (Už od mala jsem se ráda starala o mladšího bratra a sestřenici.).

Potencialitu hry je však potřeba odlišit od potenciality dozoru nad dětmi. I v př́ípadě herních činností může docházet k rozvoji dítěte - k sociálnímu rozvoji (osvojování si pravidel chování, sociálních rolí a postojů), ke kognitivnímu rozvoji (rozvoj vnímání, myšlení a řeči) i psychomotorickému rozvoji. Avšak participantky tento rozvoj explicitně nedeklarovaly. Nepoužily slovo učit nebo jeho synonyma. Při dozoru nad dětmi rozvojové možnosti nemusíme předpokládat vůbec.

U dalších participantek byl patrný příklon ke vzdělávacím činnostem, ty však byly v menšině.

\footnotetext{
3 Tučně označené výrazy používáme kvůli rychlejší orientaci čtenáře v ukázce.
} 
... mám malou sestru. Nedávno oslavila osmé narozeniny. Často jsem ji hlídala, když rodiče byli v práci. Vymýšlela jsem s ní různé hry, malovaly jsme si spolu, dívaly se na pohádky nebo jsem jí je četla, nebo jsme si spolu hrály na školu a učila jsem ji písmenka.

Vyšší rovinu tvořily činnosti, které byly organizované - formální akce v externím prostředí, tedy mimo rodinu, a to za pomoci zprostředkující osoby nebo pod jejím patronátem. Tady už vstoupily do hry organizační schopnosti participantek, schopnost regulovat a vést činnost jiných a taktéž ochutnání pocitu moci nad jinými, které se neobjevily při herní činnosti.

Ve dvanácti letech jsem mamce začala pomáhat s vedením dětského folklorního kroužku Rozmarýnek, který jsem dříve navštěvovala. Tento soubor navštěvovaly děti ve věku od 4 do 6 let.

Už při základní škole jsem pomáhala při organizaci dětských akcí na DDM.

Participantky výzkumu ve svých výpovědích vyjadřovaly potěšení být v dětském prostředí, hrát si s dětmi a vymýšlet pro ně různé činnosti. Vzhledem $\mathrm{k}$ věku participantek výzkumu můžeme konstatovat, že přes různé herní činnosti se na jedné straně může ukazovat snaha o prodloužení dětství, ale na druhé straně i podvědomý pud mateřství. Studentky jsou z hlediska svého osobnostního vývoje na průsečíku mezi dětstvím a dospělostí a to podle našeho názoru ovlivňuje i jejich pohled na děti předškolního věku.

\section{Percepce dítěte a dětství}

To, jak u budoucí učitelky vypadá koncept dítěte a dětství, naznačuje důležité konsekvence pro roli učitelky. V našich datech se ukázalo trojí chápání dítěte, které však spolu souvisí. Jednalo se o percepci dítěte jako (a) symbolu nezkaženosti, (b) symbolu emocionálnosti, (c) symbolu tvárnosti.

Participantky výzkumu se dívaly na dítě jako na čisté stvoření. $V$ dětech viděly symbol nezkaženosti. Vnímání dítěte jako prostředníka z nezkaženého světa potvrzuje naše úvahy o tom, že budoucí učitelky mateřských škol jsou už v etapě dospělosti, avšak jako by si ještě na chvíli chtěly dopřát nezkažený, čistý, bezpečný a bezproblémový svět. Ten jim zprostředkují právě děti. A vzhledem $\mathrm{k}$ tomu, že v něm chtějí pobýt co nejdéle, rozhodují se pro své povolání učitelky mateřské školy. To jim totiž zaručuje, že dětský svět neztratí. 
Děti jsou hrozně nevinné a nezkažené.

Děti v sobě mají něco nepopsatelného, kouzelného.

Líbí se mi, jak jsou malé děti tak bezprostřední, nezkažené a tak upřímné.

Z výpovědí je možné sledovat silný emocionální vztah $\mathrm{k}$ dětem. Ve výpovědích participantek byl výrazný, ale zdá se, že jej podmiňuje samotná emocionalita dětí. Tedy to, jak děti reagují na své okolí i na učitelku mateřské školy. Děti jsou symbolem emocionality. Percepce dětství má v jejich výpovědích silnou emocionální hodnotu.

Hlavním důvodem je asi to, že mě práce s dětmi baví. Líbí se mi jejich roztomilost, ale i to, jak dokáží odmalička uvažovat nad okolním světem.

Přijali mě a já jsem byla ten nejštastnější člověk na světě.

Hlavní rozdíl je podle mě v tom, že předškolní děti se učí rády. Myslím, že hlavním důvodem je to, že se tak snadno dokáží nadchnout pro věc. Myslím, že chci učit pro to jejich nadšení, energii a tvárnost.

Pozitivní emoce, jako je radost a pocit štěstí, se ukázaly taktéž jako významné faktory. Dominovaly v jejich pohledu na dětský svět a potom zprostředkovaně i na práci učitelky. Závažným způsobem ovlivnily rozhodnutí participantek vybrat si studijní cestu učitelství mateřské školy a zároveň se ukázaly být optikou, přes kterou participantky nazíraly na profesi učitelek. Ve výrocích participantek je zastoupení pozitivních emocí tak frekventované, že vzbuzuje údiv. Jednoznačně pozitivní emoce kulminovaly jako motiv pro rozhodování se být učitelkou mateřské školy ve výpovědích participantek v prvním ročníku.

Ve výpovědích participantek o dětech je možné sledovat emocionalitu i v komunikaci, která se projevovala používáním zdrobnělin. Děti pro ně byly sluníčka, trpaslíci, rarášci. Tyto jazykové prvky se na vyšších stupních školy vyskytují ojediněle.

Vztah $\mathrm{k}$ dětem předškolního věku se však u participantek výzkumu vytváří i proto, že mají možnost vidět výsledek svého snažení téměř okamžitě. Na dítě se dívají jako na symbol tvárnosti. Chápou to, že dítě předškolního věku rychle přijímá nové informace, rychle se učí nové věci a - pokud se mu nové poznávání líbí - přijímá je s nadšením a radostí. I proto participantky výzkumu oceňují u dětí jejich nadšení, energii, s níž chtějí a dokáží pracovat. Toto je prostor, kde jsou úspěšné, protože úspěch jim potvrzují právě děti, které mají z jejich snažení radost. 
Hlavní rozdíl je podle mě v tom, že předškolní děti se učí rády. Myslím, že hlavním důvodem je to, že se tak snadno dokáží nadchnout pro věc. Myslím, že chci učit pro to jejich nadšení, energii a tvárnost.

Přece jen jsou malé děti zvídavé, všude „šmejdí“, a všechno chtějí vědět.

Většina dětí v mateřské školce se chce dozvídat nové věci, děti více naslouchají, zajímají se o to, co si pro ně paní učitelka připravila ve srovnání s dětmi ze základní školy.

\section{Osobnostní vlastnosti}

Uvedené faktory ovlivňující motivaci k profesi učitelky mateřské školy, tedy preference herních činností a percepce dětství, mají silnou vazbu na specifické osobnostní charakteristiky, které se ukázaly v datech. Jednak se jednalo o vlastnosti, které byly deklarované jako reálné, jednak šlo o jakousi vizi vlastností, které participantky nabydou, když se stanou učitelkami.

Pojítkem všech deklarovaných vlastností byla empatie. Participantky popsaly široké spektrum př́buzných vlastností, jako je ohleduplnost, schopnost porozumět dětem, ochota pomáhat, trpělivost, rozvážnost, taktnost nebo entuziazmus. Všechny tyto vlastnosti se aktualizují ve vztahu k dítěti, čímž studentky vyjádřily schopnost pochopit jejich perspektivu a chápat jejich potřeby (ovšem nějak hluboko nespecifikované). Na druhé straně se vyskytlo i doplňující hledisko - jak participantka vnímala své charizma v kontaktu s dětmi (děti přitahuji).

\section{Rolové vzory}

Nejdůležitější osobou, s níž byly participantky v dětství svázány, byla matka. Jednak podporovala emocionalitu $\mathrm{v}$ prostředí rodiny a jednak posilňovala tvorbu genderových stereotypů. Herní činnosti, jak jsme ukázali, byly velmi rozšířenou formou předprofesionálních aktivit budoucích učitelek mateřské školy. Sehrály významnou úlohu při formování jejich představ a postojů. Taktéž vedly k rozhodnutí dát se na učitelskou dráhu. Uskutečnily se v prostředí rodiny. Participantky hlídaly a hrály si zejména se sourozenci a dětmi př́íbuzných. Tyto aktivity byly realizovány s vědomím matky a často na základě jejího svolení nebo pod její přímou či nepřímou supervizí. Matka vystupovala vůči participantce jako rolový vzor.

V biograficko-narativní terminologii je rolovým vzorem člověk, který výrazným způsobem ovlivnil rozhodování, činnost nebo postoje subjektu 
(Kelchtermans \& Vandenberghe, 1994). V našem př́padě matka jako by v sobě esenciálně zosobňovala všechny uvedené vlivy - feminitu, emocionalitu a poskytování herních příležitostí (je matkou dětí, které participantky hlídaly a hrály si s nimi). Nejen to. Matka působila také jako model vychovatelky.

Když jsem byla malá, mamka mi ř́kala, že se na svět dívám přes růžové brýle. Myslela jsem si, že svět a lidé v něm jsou dobří. Že když se budu chovat tak, jak mám, tak se i ostatní budou ke mně chovat stejně. Postupem času jsem zjistila, že realita je jiná. Učila mě, abych se na věc nebo na člověka a jeho jednání dívala z více úhlů pohledu. Vždy, když se objevila situace, která si žádala diskuzi, dokázaly jsme o ní mluvit třeba i hodiny. Vyměňovaly jsme si svoje názory a vzájemně je respektovaly. A takto to funguje dodnes.

V jiných výzkumech o stávání se učitelem se jako rolový vzor objevuje konkrétní učitel. Inspirace učitelem - vzorem je tak silně empiricky doložená, že se považuje za univerzálně platnou. Např́iklad ve výzkumu Maldereza et al. (2007) až 71 učitelů z 85členného britského vzorku deklarovalo, že se rozhodli stát učiteli pod vlivem svého učitele. U nás např. Kasáčová (1996) zjistila, že $45 \%$ respondentů z jejího vzorku studentů učitelství 1 . stupně ZŠ se chtělo stát od malička učiteli. Na druhé straně až $15 \%$ respondentů deklarovalo, že byli formováni rodičovským vzorem.

Vlivné osoby inspirují a motivují mladé lidi svým charismatem, které posilňuje jejich lidské a odborné působení. Do hry však vstupují další dva faktory. Učitel je osobou, která provází dítě školou. Dítěje ve školním prostředí 5-7 hodin denně, 5 dní v týdnu, deset měsíců v roce. Jde o intenzivní působení, navíc realizované během dlouhého úseku života, takže vliv učitele nemůže být malý, ani přehlédnutelný. Výzkum ukazuje, že současní učitelé mají velmi živé vzpomínky na své učitele. Dokáží si rychle vybavit jejich charakteristiky, jména i různé epizody z jejich působení (Timmerman, 2009). Za druhé, většina učitelů na začátku školní docházky, kdy je tento vliv největší, jsou ženy. Díky své feminitě působí hlavně na žačky, které v nich vidí profesní vzor.

Učitelky jako rolové vzory se vyskytly ve výpovědích našich participantek jen ve třech případech, což je překvapivě nízký počet. Je však zřejmé, že model učitelky - přesněji vychovatelky - tu působil prostřednictvím matky. Matka tedy působí jako rolový vzor tam, kde v jiných výzkumech působí učitelé. Ovšem na rozdíl od těchto výzkumů nejde $v$ našem případě o učitele základních a středních škol, což mohlo sehrát rozhodující úlohu ve výpovědích participantek. 
$\mathrm{V}$ popisech tři vlivných osob byl rozhodujícím modelem pro volbu studia učitelství rodinný příslušník - žena, nikoliv muž. Tím se nejen reprodukovala feminita, ale také byl zabezpečen mezigenerační transfer profese $\mathrm{v}$ rodině. Šlo o tři různé situace. Prvním případem byly osoby popsané se zamlčenou profesionalitou. Participantka nepodala jejich odborný popis nebo profesní charakteristiku. Hovořila jen o tom, že jí umožnily poznat život v tomto zařízení, tj. jeho typické stránky.

Obě dvě babičky pracovaly celý život ve školce, takže jsem měla možnost poznat život učitelky v MŠ. Myslím, že je to práce př́nosná a hezká.

Druhý případ představuje osoba podávaná s koncentrovanou pracovní charakteristikou a s velmi silným afektivním zabarvením. Participantka sice napsala o svém vzoru jen tři věty, ale ty obsahují slova, která poukazují na emocionalitu působení rolového modelu.

Už když jsem byla já v MŠ, tak se mi hrozně líbilo, jak s námi p. uč. pracuje. Bavilo mě všechno, co pro nás vymýšlela. Vždy mě dokázala něčím zaujmout a překvapit.

Třetím případem je negativní vliv, kdy osoba vystupuje jako antivzor.

Jsem zaměřena spiše na humanitní studia, ale napřs studium psychologie, považuji za velice náročné. Na druhou stranu nikdy jsem nechtěla být učitelka. Mám totiž už doma dvě. Moje mamka učí na prvním stupni základní školy a moje sestra, která před pár dny udělala státnice, je už také učitelka, jen s aprobací zaměřenou na střední školy. Pro studium učitelství pro mateřské školy jsem se rozhodla hlavně proto, že mám dvě neteře. Do doby, než se narodily, jsem neměla žádnou praxi s dětmi v předškolním věku. Když jsem se po maturitě rozhodovala, kam jít, tak měla neteř přes půl roku. Byla ještě malinká, a mě tahle možnost nenapadla. Ted' jsou jí dva a půl, a když můžu, trávím s ní volný čas.

V této ukázce je zajímavé, že dva antivzory jsou uvedeny jako kontrastz požitku participantky při vlastní činnosti s malými dětmi. Tím tato participantka - at' už vědomě, či nevědomě - demonstrovala, že nikoliv profesionalita učitelek, ale záliba v dětech byla hnacím motivem jejího rozhodnutí stát se učitelkou mateřské školy. To potvrzuje naši předcházející interpretaci o primární úloze hry s dětmi (koncept prodlouženého dětství) jako inspiraci při rozhodování o studijní cestě. 
Percepce činností učitelky mateřské školy

Předcházející analýza se soustředila na faktory, které ovlivňovaly rozhodnutí stát se učitelkou $\mathrm{v}$ mateřské škole. U participantek se postupně rodilo víc než toto rozhodnutí - vyvíjel se koncept učitelství. Ten byl ovlivněn nejen už uvedenými rolovými vzory, ale také osobními zkušenostmi a poté také odbornými vědomostmi, které získaly na počátku studia na vysoké škole (participantky v 1 . semestru) nebo v jejím středu (participantky ve 3 . semestru).

Participantky výzkumu vnímaly své poslání budoucích učitelek mateřských škol jako (a) př́ípravu dítěte na život, (b) podporu osobnosti dítěte, (c) podporu role školáka.

... já jim chci ten rozlet do života ulehčit.

... právě v mateřské školce dostávají velmi základní „rady“ do života.

Mám dobrý pocit z toho, že já jako učitelka jim můžu pomoct usnadnit vstup do určité samostatnosti. Děti si ve školce musí postupně zvyknout na to, že musí být nějakou dobu bez maminky a tatínka. A já jsem ráda, že jim můžu ulehčit tento vstup láskyplnou péčí. Také, že jim něco nového a základního do života předám. Něco bude na výroku „to, co nejvíc potřebuji, jsem se naučila v mateřské škole“.

V těchto výrocích se odehrává jakoby odkrývání reálného světa, které může postupně zprostředkovávat mateřská škola. Stává se tak prostorem, který vytváří možnosti na př́pravu na život. Přibývají kontakty s vrstevníky, a posilňují tak sociální funkci mateřské školy. Učitelka mateřské školy zprostředkovává kontakty, vytváří jakýsi pomyslný most mezi realitou života a ochranářským zázemím rodiny. Realita života je nastavena i přes konflikty, které mezi dětmi vznikají. Do struktury představ o profesi učitelky zapadá i verze vnímání učitelek školy v dichotomii dobré (spravedlivé) a zlé (nespravedlivé) učitelky (blíže Pupala \& Branická, 2002). Dobrá učitelka je spíše spojována s mateřskou školou, kde se ve vztahu k funkcím mateřské školy dostávají více do popředí partnerské pozice a vztahy s dětmi, ale také rodiči. $\mathrm{V}$ mateřské škole je vztah učitelky k dítěti doprovázen náklonností, důvěrou a partnerstvím. I proto je pozice učitelky mateřské školy ve vztahových rámcích dítě-škola-rodina jedinečná (viz Kaščák, 2010).

Důležitost komunikace s rodinou si participantky výzkumu uvědomovaly v plném rozsahu. Především ve výpovědích z druhého ročníku je možné zřetelně rozlišit i jakousi obavu ze vstupování do konfliktů s rodiči. 
S komunikací s rodiči jsem se za svou dosavadní praxi ještě nesetkala. Na tuto část práce v mateřské škole se popravdě moc netěším, ale vím, že je její nedílnou součástí.

Participantky výzkumu prezentovaly ve svých výpovědích představu o tom, kam by se mohlo ubírat jejich edukační působení. Ve výpovědích jasně probíraly svoji úlohu při podpoře rozvoje osobnosti dítěte.

Chci zasáhnout do růstu a vzdělávání dětí.

Chci klást dětem správné otázky a podněcovat jejich touhu po poznání a vědění a po tom, aby se dokázaly vcítit do druhých lidí a byly k nim ohleduplné. V dnešní době je to velice důležité, protože je všude plno různých kultur. (2. ročník)

Především bych dětem chtěla nabídnout podněty $\mathrm{k}$ tomu, aby byly ve svém životě samostatnými a plné rozvinutými bytostmi. (2. ročník)

Se vzděláváním ostatně souvisí i úloha učitelky mateřské školy zaměřená na př́pravu dítěte na roli školáka. Participantky výzkumu jasně deklarovaly percepci vztahů mezi mateřskou a základní školou. Věděly, že na vstup do první tř́idy mohou předškoláka připravit. Je to podle nich jeden $\mathrm{z}$ nejsilnějších a nejsmysluplnějších úkolů, které mateřská škola má ve svém edukačním rámci.

Myslím si, že učitelka v mateřské škole přijímá tu zodpovědnost, že dítě jdoucí z mateřské školy přežije první třídu, že na to bude připravené nejen po psychické, ale také fyzické stránce.

Mám k malým dětem kladný vztah a bavilo by mě se jim věnovat. Pomáhat jim s učením a přípravou do první třídy.

Při sledování výpovědí participantek výzkumu nacházíme uvědomění si důležitosti edukačního působení mateřské školy. Z výpovědí participantek je zřetelná i socializační funkce mateřské školy. Dítě se v mateřské škole díky různým situacím, do nichž se dostává, stává sociální bytostí se vším, co k tomu patří. Učí se normy, hodnoty, které jej obklopují, postupně si je osvojuje a začleňuje se tak do reálného života společnosti. Mateřská škola tak vytváří podmínky na to, aby jejím prostřednictvím toto osvojování kultury probíhalo.

\section{Proces rozhodování}

Rozhodnutí o volbě studia mladý člověk sice vyslovil v jednom okamžiku, předchází mu ale proces rozhodování, který může být různě dlouhý a intenzivní. Proces rozhodování zahrnuje přemýšlení, úvahy, bilanci zkušeností 
a využití poradenství osob. Obyčejně jde o různé vlivy, které se prolínají a spolupůsobí, i když jeden z nich může být nejsilnější. Může se jednat o několik kroků, kterými se mladý člověk postupně dostává k finálnímu rozhodnutí.

Ve výrocích našich participantek je zřetelné první rozhodnutí - předběžný verdikt, který se potom prohluboval a zesiloval. Následující ukázka překvapuje velmi přesným zobrazením situace, která znamenala zvrat.

Poprvé mě napadlo, že chci být učitelkou, když jsem vyzvedávala svoji malou sestru ze školky. Na ten pocit, kdy jsem poprvé uviděla ty malé děti, jak si hrály a skotačily, nikdy nezapomenu.

Většina rozhodování nebyla hladká a jednoznačná, provázela je rozhodovací dilemata, kdy participant zvažoval a opakovaně přehodnocoval různé faktory a situace. Následující ukázka dobře vystihuje dilemata v procesu rozhodování se, situace, které ovlivňovaly rozhodování a taktéž dlouhý časový interval rozhodování.

Od mala jsem chtěla být paní učitelkou. Když měla má sestra asi 5 let, tak jsme si hrály na školu a já ji učila psát, počítat a abecedu. V deváté tř́ídě jsem ani nepřemýšlela a střední škola pedagogická byla okamžitá volba. Potom na stř̌ední jsem měla takové výkyvy. Chvíli jsem si tím byla jistá, pak zase ne. To, že jsem si tím nebyla někdy jistá, bylo zapř́činěno průběžnou praxí v MŠ ve Zlíně. Myslím si, že jsem kreativní typ a nelíbilo se mi, že to nemůžu využít. Vedoucí praxe nám přesně „nalajnovala“, co si máme na př́ště připravit. Potom jsem ale měla praxi souvislou a p. učitelka mě jen řekla téma a nechala mi „volnou“ ruku. To jsem se zase dostala zpět do fáze - chci to dělat.

Pokud se na rozhodování o budoucí profesi díváme chronologicky, tak své první rozhodnutí situovaly některé participantky už do předškolního věku. To je překvapující, protože tehdy je mladý člověk profesně ještě velmi nezralý. Velkou úlohu při tom sehrála emocionalita situace, romantické vzpomínky na vlastní dětství a na docházku do mateřské školy. Rané rozhodnutí stát se učitelkou mateřské školy dokumentovala izraelská studie (Court et al., 2009) i studie slovenských učitelů (Gavora, 2002). V př́padě učitelek sekundárního vzdělávání se toto rozhodnutí uskutečňuje často v pozdějším věku (Timmermann, 2009) a je neobyčejně pevné (Thornton et al., 2002).

Toto povolání mám vysněné snad od doby, kdy já jsem byla ještě ve školce.

Práce s dětmi mě bavila již od útlého věku. 
V životě žáka vystupují dvě křižovatky, na kterých se musí rozhodnout o studijní cestě. První křižovatka leží před ukončením základní školy, druhá před koncem střední školy. Po ukončení základní školy 50 \% participantek zvolilo střední pedagogickou školu, z níž je logický přechod na studium učitelství mateřské školy na vysoké škole. Některé participantky však přišly na toto studium z jiných středních škol. Nebylo to jen gymnázium, které je z hlediska budoucí profesní orientace neutrální, ale také z odborných škol: obchodní akademie, hotelnictví a turismu, oboru kosmetičky.

Pro čtvrtinu participantek představovalo studium učitelství druhou volbu. Dospěly k němu oklikou po neúspěšném pokusu dostat se na jinou vysokoškolskou specializaci (psychologie, vychovatelství). Pro některé byla tato odbočka ještě delší - první rok studia na fakultě prvotní volby se ukázal jako chybný. Po něm studentka přešla na učitelství pro mateřské školy, s nímž je spokojená. Tři participantky se sem dostaly z ekonomie, jedna z učitelství pro střední školy (tělesná výchova a zeměpis). V této souvislosti je zajímavé zjištění Šmelové a Nelešovské (2009), že až 18 \% posluchaček tohoto oboru na Pedagogické fakultě UP v Olomouci se tam dostalo hlavně proto, aby získaly bakalářský titul, tedy motivace stát se učitelkou v mateřské škole byla až sekundární.

V některých případech bylo hledání studijní cesty po maturitě dramatické.

Když jsem dokončila střední pedagogickou školu, obor výchova dětí předškolního a mladšího školního věku, nedokázala jsem si představit, že bych tuto práci dělala do konce života. Připadala jsem si př́iliš mladá a hledala jsem něco jiného, něco, co by mě bavilo víc. Zkoušela jsem různé obory jako logopedie, dramaterapie, sociální patologie a prevence, obecná speciální pedagogika, výtvarná výchova se zaměřením na vzdělání apod. Po dvou letech jsem ale zjistila, že to, co chci opravdu dělat, a to, co mě baví ze všeho nejvíce, je práce v mateřské škole. Proto jsem se přihlásila na tuto školu a udělám všechno proto, abych ji úspěšně dokončila.

Volba studijní cesty a okolnosti, které vedly k tomuto rozhodnutí, nejsou jen indikátorem zájmu participantek o studium učitelství, ale zároveň mohou naznačovat vztah $\mathrm{k}$ profesi a zprostředkovaně $\mathrm{k}$ retenci $\mathrm{v}$ této profesi. Proto je důležitým ukazatelem hloubka přesvědčení o zvolení si profese učitelky. Ta byla u participantek velká. 
Práce s dětmi mě naplňuje. Je to můj cíl, kterého chci v životě dosáhnout. Chci dělat práci, která mě baví, bude mi přinášet uspokojení a potěšení. A za tímhle cílem si půjdu.

Být učitelkou v MŠ je jedno z nejkrásnějších povolání.

V této souvislosti se vnucuje paralela s pocitem být povolán stát se učitelem, který měli participanti výzkumu Whitbecka (2000). Pocit povolanosti (calling) je možné chápat jako nejvyšší formu zaujatosti či motivace, danou mladým lidem odněkud z hůry. Nadšení participantek stát se učitelkami je však v ostrém kontrastu se všeobecně malou atraktivností učitelské profese (např. Kolektív autorov, 2006, s. 90), která vyúst'uje do nízkého procenta absolventů učitelských fakult, kteří nastoupí na profesní dráhu učitele a zůstanou v ní. Důvodem jsou obyčejně materiální problémy (nízké mzdové ohodnocení, nedostatečné materiálně-technické vybavení škol) a velké pracovní zatížení. V pozadí je také nenaplnění profesních očekávání učitelů. Tento poslední faktor je možnou hrozbou, že ani participantky výzkumu nezůstanou mimo tento převažující trend. Nadšení pro tuto profesi však projde po nástupu do mateřské školy empirickým testem reality, který prověří validitu jejich zájmu.

\section{Dynamika rozvoje mezi prvním a třetím semestrem.}

Zbývá se ještě vyjádřit k rozdílu mezi daty získanými v obou semestrech. Porovnání by mělo umožnit pochopit dynamiku rozvoje motivů i vlastností studentek. $\mathrm{V}$ obou případech se participantky vyjádřily $\mathrm{k}$ motivům volby profese velice podobně. Dominovaly vzpomínky na herní činnosti a percepce dítěte a dětství. Tím se vlastně data triangulovala. Přidanými tématy v třetím semestru byla percepce profesních potencialit studentek, zejména empatie. Pedagogické praxe různého typu, které studentky absolvovaly $\mathrm{v}$ průběhu tří semestrů, umožnily získat př́mou zkušenost s edukačním procesem v mateřské škole. I když studentky většinou reflektovaly pozitivní zkušenosti, překvapily je organizační požadavky edukačního procesu.

Do doby, než jsem začala tento obor studovat, tak jsem nikdy neslyšela o pojmech jako rámcový vzdělávací program, třídní vzdělávací program, řízená činnost a tak dále. Vůbec jsem netušila, že se každá učitelka v mateřské škole musí řídit dle nějakého plánu, vše musí tak pečlivě sepisovat a připravovat a především mít předem každou činnost a aktivitu tak podrobně promyšlenou i se všemi svými možnými alternativami. Abych řekla pravdu, tak mě nikdy předtím nenapadlo, že denní program ve školce je tak striktně nadiktován a každá činnost má své určené místo v daném čase. 
Tyto myšlenky představují určitý protipól k percepci činnosti učitelky mateřské školy s převahou her a prodlouženého dětství. Další část pedagogické praxe a pak i realita profese jim pravděpodobně přinese další zkušenosti, které povedou ke korekci původních prekoncepcí.

\section{Závěr}

Předcházející zjištění nyní podáme v koncentrované podobě ve formě modelu integrujícího témata, která byla extrahována z dat, a jejich souvislosti.

Rozhodnutí stát se učitelkou mateřské školy je výsledkem předcházejících interakcí mezi osobnostními charakteristikami subjektu a externími faktory. U našich participantek se ukázaly dva významné osobnostní faktory - feminita a emocionalita. Feminita je specifická zkušenostní optika, pod jejímž vlivem (můžeme hovořit o filtru) participantky vnímají svět a vyhledávají činnosti a situace, které vyhovují této optice. Zároveň feminita zužuje profesní uplatnění a předprogramuje ženské subjekty stát se učitelkami, jelikož učitelská profese je v naší tradici dominantně obsazována ženami. ${ }^{4}$ Emocionalita přináší citlivost při vnímání světa a představuje energizující prvek jednání, který souvisí s feminitou. Silná emocionalita však vytlačuje kontrolu nad racionalitou. Feminita a emocionalita byly propojeny empatií jako silnou osobnostní vlastností, která je podmínkou pro pochopení perspektiv a potřeb dětí.

Co se týče externích vlivů, velmi silným determinantem je prostředí rodiny. Rodina působí jednak jako kohezní činitel jejích členů a jednak jako činitel profesní socializace, protože podporuje volbu stát se učitelkou, či dokonce př́mo poskytuje rolové vzory pro tuto profesi. S rodinou souvisí pestré herní činnosti, které participantky realizovaly s dětmi, a to bud' jako dozorující, nebo dokonce jako řídící subjekty této činnosti. Během nich participantky získávaly předprofesionální zkušenosti, tj. poznatky a přesvědčení o náplni a charakteru činností s dětmi a jejich vlastní roli v nich. Byly však založeny

\footnotetext{
4 Zajímavým tématem by bylo zkoumání motivů učitelství u studentů - mužů. Ti jsou však velmi ř́́dkým úkazem. Získat takové participanty výzkumu bylo nemožné. Připomeňme, že dominance učitelek má historické kořeny. Když koncem 18. století začaly vznikat školy pro dívky, cíl přípravy se koncentroval na zvládnutí role v domácnosti. Se vznikem státních i soukromých škol se otevíral prostor pro nové profesní uplatnění žen v roli učitelek. Vedení škol začalo zaměstnávat více žen, které účinně a hlavně levně zprostředkovávaly vzdělání širokým masám (levně proto, že ženám se vyplácely nižší mzdy než mužům). Na konci 19. století se učitelství stalo ženskou profesí.
} 
jen na hrubé empirické, a nikoliv na teoretické reflexi. Emocionalita, dětský svět i věková blízkost participantek $\mathrm{k}$ dětem generovaly percepci učitelství jako prodlouženého dětství. Jde vlastně o sekundární prožívání vlastního dětství, avšak na pozici posunuté k dospělosti. Vlivem toho se vznikající edukační filozofie participantek projevuje jako ochranářská, naplňující se rolí průvodce dítěte z dětství do života, včetně vstupu do školního života. Edukační filozofie se propojuje s percepcí dítěte a dětství, která je založena na jejich etické prostotě, kognitivní tvárnosti a přirozené emocionalitě. Tím se základní determinační faktory dostaly do kongruence a vyúst'ují v rozhodnutí subjektu vstoupit na učitelskou dráhu, v tomto případě na profesionalizaci ve vysokoškolském studiu.

Edukační filozofie jako jistá forma základu předučitelské identity v příznivých podmínkách nestagnuje. V průběhu studia učitelství na vysoké škole se pod vlivem teoretického studia a pedagogické praxe rozvine do prekonceptu učitelství, který se potom v průběhu zaměstnání učitelky pozvedne na plnou profesní identitu učitele. Ani ta však není definitivní. Naopak, bude se dynamicky formovat a rozvíjet po dobu celé učitelské dráhy subjektu.

Motivy stát se učitelem nejsou jen důležitým výzkumným tématem, ale mají i silné aplikační souvislosti. Vysokoškolské pedagogy musí zajímat, co vedlo studentky k výběru profese a do jaké míry reflektují vlivy, které k rozhodnutí přispěly. Odpověd' na tuto otázku často ukazuje, zda absolventka nastoupí na místo učitelky a jak dlouho učitelkou zůstane. Při přijímání uchazečů o studium je důležité diagnostikovat vstupní stav konceptu učitelství a v průběhu studia sledovat, jak a v kterém směru se mění.

\section{Literatura}

Blumer, H. (1969). Symbolic interactionism. Perspective and method. Englewood Cliffs: PrenticeHall.

Braun, V., \& Clarke, V. (2006). Using thematic analysis in psychology. Qualitative Research in Psychology, 3(4), 77-101.

Buckenham, M. A. (1998). Socialisation and personal change: A personal construct psychology approach. Journal of Advanced Nursing, 28(4), 874-881.

Burkovičová, R., Gobelová, T., \& Seberová, A. (2011). Analýza profesijných činností učitelov v Česku. In B. Kasáčová, et al., Učitel' preprimárneho a primárneho vzdelávania (s. 231-284). Banská Bystrica: UMB.

Court, D., Merav, L., \& Ornan, E. (2009). Preschool teachers' narratives: A window on personalprofessional history, values and beliefs. International Journal of Early Years Education, 17(3), 207-217. 
Elizabeth, V. (2007). Another string to our bow: Participant writing as research method. Forum Qualitative Sozialforschung / Forum: Qualitative Social Research, 9(1), Art. 31. Dostupné z http://www.qualitativeresearch.net/index.php/fqs/article/view/331/723

Epting, F. R., \& Paris, M. E. (2006). A constructive understanding of the person: George Kelly and humanistic psychology. The Humanistic Psychologist, 34(1), 21-37.

Eren, A. (2012). Perspective teachers' interest in teaching professional plans about teaching and career choice satisfaction: A relevant framework? Australian Journal of Education, 56(3), 303-318.

Gavora, P. (2002). Rozhodnutie stat' sa učitel'om - pohlad kvalitatívneho výskumu. Pedagogická revue, 54(3), 240-256.

Gergen, K. J. (1985). The social constructivism in modern psychology. American Psychologist, $40(3), 266-275$.

Hlad'o, P., \& Drahoňovská, P. (2012). Rozhodování žáků základních a středních škol o dalším studiu a práci v pohledu žáků i jejich rodičů. Praha: VÚP.

Juklová, K. (2013). Začínající učitel z pohledu profesního vývoje. Hradec Králové: Gaudeamus.

Kasáčová, B. (1996). Očakávania a predstavy študentov učitel'stva a ich postoje k pedagogickopsychologickej príprave. Pedagogická revue, 48(7-8), 311-317.

Kasáčová, B. (2005). Reflexívna výučba a reflexia v učitelskej príprave. Banská Bystrica: Pedagogická fakulta UMB.

Kaščák, O. (2010). Škola ako rituálny priestor. Trnava: TUT, VEDA.

Kariková, S. (2004). Špecifiká profesijnej dráhy učiteliek. Prešov: MC.

Kelchtermans, G., \& Vandenberghe, R. (1994). Teachers' professional development: A biographical perspective. Journal of Curriculum Studies, 26(1), 45-62.

Kelly, G. A. (1955). The psychology of personal constructs. New York: Norton.

Kolektív autorov. (2006). Profesijný rozvoj učitela. Prešov: Metodicko-pedagogické stredisko.

Lukas, J., \& Švaříček, R. (2007, září). Reflexe zkoumání identity učitele. Příspěvek prezentovaný na 15. výroční konferenci České asociace pedagogického výzkumu, České Budějovice.

Malderez, A., Hobson, A. J., Tracey, L., \& Kerr, K. (2007). Becoming a student teacher: Core features of the experience. European Journal of Teacher Education, 30(3), 225-248.

Mallon, R. (2007). A field guide to social construction. Philosophy Compass, 2(1), 93-108. Dostupné z http://xcelab.net/rm/wp-content/uploads/2008/09/mallon-field-guide-tosocial-construction-2007.pdf

Pupala, B., \& Branická, M. (2002). Medzi materskou a základnou školou. Čo očakávajú deti od školy. Pedagogika, 52(3), 337-345.

Richardson, L. (1994). Writing as a method of inquiry. In N. K. Denzin \& Y. Lincoln (Eds.), Handbook of qualitative research (s. 516-528). London: Sage.

Spilková, V., et al. (2004). Současné proměny vzdělávání učitelů. Brno: Paido.

Stuchlíková, I. (2006). Role implicitních procesů při utváření profesní identity budoucích učitelů. Pedagogika, 56(1), 31-44.

Šmelová, E., \& Nelešovská, A. (2009). Učitel mateřské školy v reflexi současných proměn. Olomouc: Pedagogická fakulta UP.

Švaříček, R. (2009). Narativní a sociální konstrukce profesní identity učitele experta. (Disertační práce). Brno: FF MU. 
Timmerman, G. (2009). Teacher educators modelling their teachers? European Journal of Teacher Education, 32(3), 225-238.

Thornton, M., Bricheno, P., \& Reid, I., (2002). Students' reasons for wanting to teach in primary school. Research in Education, 67(1), 33-43.

Whitbeck, D. A. (2000). Born to be a teacher: What am I doing in a college of education? Journal of Research in Childhood Education, 15(1), 129-136.

Wiegerová, A., \& Lampertová, A. (2012). A teacher's diary as a research instrument. Forum dydaktyczne, 8(9-10), 22-29.

\title{
Autoři
}

doc. PaedDr. Adriana Wiegerová, PhD., Univerzita Tomáše Bati ve Zlíně, Fakulta humanitních studií, Ústav školní pedagogiky, Mostní 5139, 76001 Zlín, e-mail: wiegerova@fhs.utb.cz

prof. PhDr. Peter Gavora, CSc., Univerzita Tomáše Bati ve Zlíně, Fakulta humanitních studií, Centrum výzkumu, Mostní 5139, 76001 Zlín, e-mail: gavora@fhs.utb.cz

\section{Why do I want to become a preschool teacher? The perspective of qualitative research}

\begin{abstract}
The paper reports on investigation of motives of choosing preschool teacher profession by young people. The sample consisted of 29 students of bachelor programme in preschool education at a university in Moravia who did thematic writing on motives of wanting to be a preschool teacher, on circumstances that influenced their decision as well as about their notion of the child and childhood and conception of performance of the preschool teacher. The thematic writing was conducted twice, in the first and the third semesters of the study. The texts were analysed to obtain concepts and themes that explained the research questions. The findings show that the decision of becoming a preschool teacher is the result of previous complex interactions between personal characteristics of the subject and external factors which, however, are not perceived passively but are filtered through previous attitudes and beliefs. The two most important personal factors are feminity and emotionality. As concerns the external determinants, a strong factor is the subject's family which provides opportunities for participation in plays with children of family members and others, as well as role models. These pre-professional experiences resulted in the concept of preschool teaching as a prolonged childhood. The educational philosophy of the subjects rests on three teacher's roles, i.e. protector of the childhood, usher of the child to life, and guide of the child to school life.
\end{abstract}

Keywords: preschool teacher, decision to become a teacher, feminity, emotionality, pre-professional experiences, concept of teaching 